\author{
Aleksandra D. Joksimović \\ Junior Researcher \\ University of Belgrade \\ Faculty of Mechanical Engineering \\ Emil A. Veg \\ Assistant Professor \\ University of Belgrade \\ Faculty of Mechanical Engineering \\ Vojislav D. Simonović \\ Assistant Professor \\ University of Belgrade \\ Faculty of Mechanical Engineering \\ Mladen M. Regodić \\ Teaching Assistant \\ University of Belgrade \\ Faculty of Mechanical Engineering \\ Goran B. Šiniković \\ Associate Professor \\ University of Belgrade \\ Faculty of Mechanical Engineering \\ Nenad Gubeljak \\ Full Professor \\ University of Maribor \\ Faculty of Mechanical Engineering \\ Slovenia
}

\section{Implementation of Inverted Classroom Methodology in 3D Modeling Course}

\begin{abstract}
More than one decade 3D modeling in SolidWorks is taught at the Faculty of Mechanincal Engineering at the University of Belgrade (Serbia). As every new skill that has to be mastered, SolidWorks software package demands well-tailored teaching methodology. The best possible way of teaching would be one-on-one tutoring. One teacher per student, who would be absolutely focused on student's task completion, would provide the best results. Unfortunately, due to the lack of teaching staff and vast number of students this approach isn't possible. Instead, one teacher would present the $3 D$ modeling task of interest on the video presenter to a group of 80 students. They would follow the whole presentation and only when the whole presentation ends, students would split into four classrooms with 20 computers each, and practice the presented tasks. During the last decade few major problems in these teaching methods were recognized. A new teaching approach was implemented. This paper presents a novel teaching methodology and achieved results in the teaching process improvement.
\end{abstract}

Keywords: Education in engineering, 3D modeling, inverted classroom

\section{INTRODUCTION}

Traditionally, any engineering curriculum at European universities has included engineering design graphics subjects in which, during at least one academic year, students receive basic training in the systems of representation, sketching, technical drawing, and CAD [1, 2]. Thus, at the Faculty of Mechanical Engineering (University of Belgrade), during the second semester of the first year, a course in Engineering Graphics was organized. During the 15-week course, students study the basics of modelling in the SolidWorks software package. SolidWorks was chosen because it is the easiest graphics software for all kinds of graphics communication [3]. Prior to the implementation of the novel teaching concept, there were various problems.

First, students had to memorize or take notes about presented modeling processes, and could practice them only later when the lesson is finished. After one-hour lecture, the amount of new information was extremely challenging for the students. Small steps, crucial for the learning process, were impossible to implement.

Second, the lectures lacked in interaction. Students couldn't simultaneously implement presented instructions, so they couldn't encounter potential problems (in the modelling process) which could be the topic for discussion.

Third, due to their passive role during classes students were noticeably bored. Boredom is a well-

Received: June 2018, Accepted: December 2018

Correspondence to: Aleksandra Joksimović, PhD

Student, Faculty of Mechanical Engineering,

Kraljice Marije 16, 11120 Belgrade 35, Serbia

E-mail: ajoksimovic@mas.bg.ac.rs

doi:10.5937/fmet1902310J

(C) Faculty of Mechanical Engineering, Belgrade. All rights reserved known problem in the learning process [4].

In 2014 we heard about the inverted classroom approach. An inverted, or flipped, classroom, where content delivery includes video lectures watched outside of the classroom, is a method that can free classroom time for learner-centered activities such as active and problem-based learning [5].

After deciding to implement this method video tutorial that follows the course were recorded. Video tutorials are available free of charge on YouTube and they could be found on the channel named „Inženjerska grafika". This was followed by changes in teaching process organisation and all together provided prominent improvement in students' results.

\section{COURSE OUTLINE}

The course is divided into three parts. Each part lasts for four weeks and after each part students have to do the test. The first part of the course is the most intensive, because students are, at the same time, introduced to the program and they have to master the basics of modelling. In the second part of the course, students are expected to be able to model all elements of an assembly and mate them properly.

In the final part of the course, expectations are higher and students should model elements with more complex geometry.

Through the modelling process, students unconsciously begin to think about the technology of production of these elements. It is very important that the student can imagine every element in the three dimen-sional space. At the end of the course, students ack-nowledge the importance of 3D modelling, as a nece-ssary part of the numerical and geometric calculations [6-8]. 


\subsection{First part of the course}

Topics are connected with introduction to SolidWorks, the working environment and basic commands. The highlight is on the dimensioning and positioning of the sketch. In the first part of the course it is demanded from students to perform the modelling of two specific elements (Exercise 1 and 2).
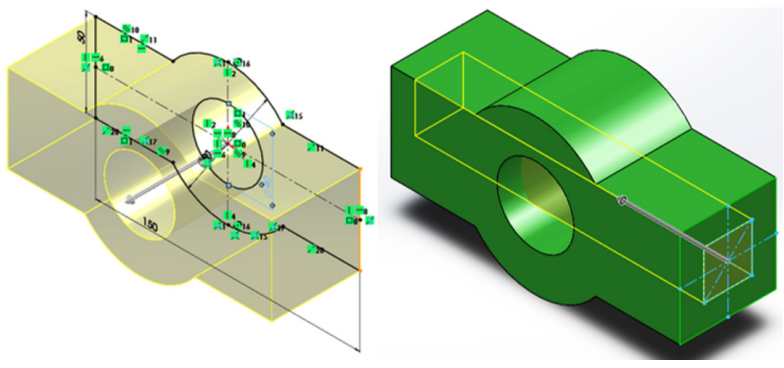

Figure 1. Extruded Boss/Base and Extruded Cut

The commands needed for the first exercise are: Extruded Cut, Extruded Boss/Base and Fillet. An example of a first exercise is given in Figure 2. Every element within the first exercise should be done in maximum five operations.
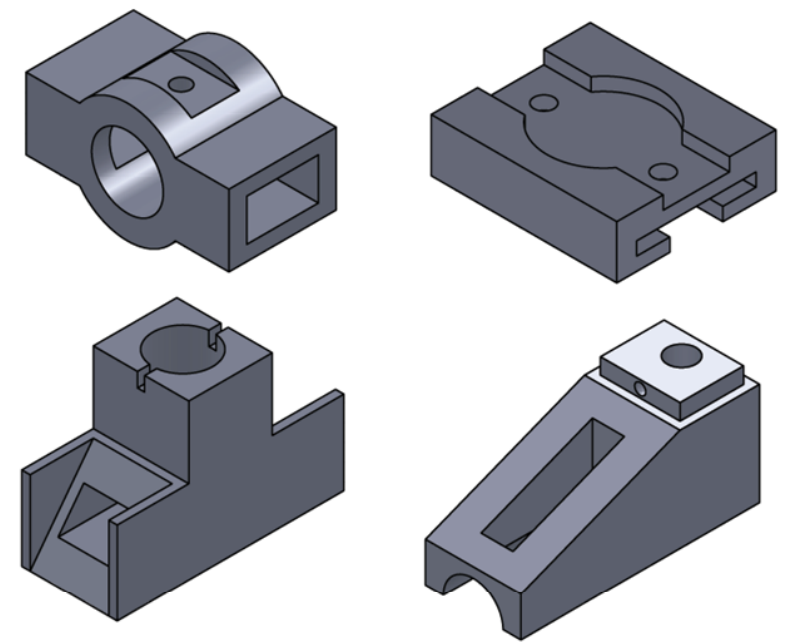

Figure 2. Models of first exercise

For the second exercise the student must learn the following commands: Revolved Boss/Base, Revolved Cut, Chamfer, Hole wizard and Cosmetic thread.

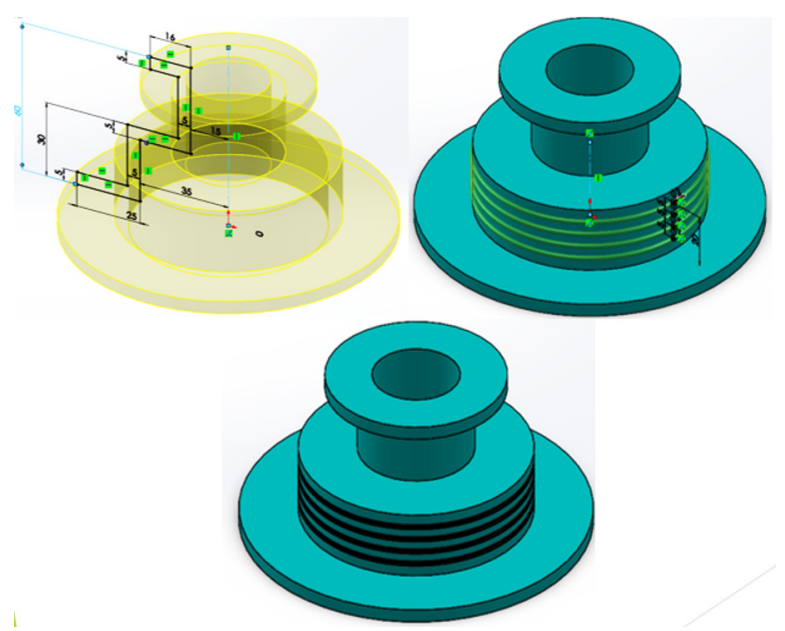

Figure 3. Revolved Boss/Base and Revolved Cut
Some of the exercise models are shown in Figure 4.
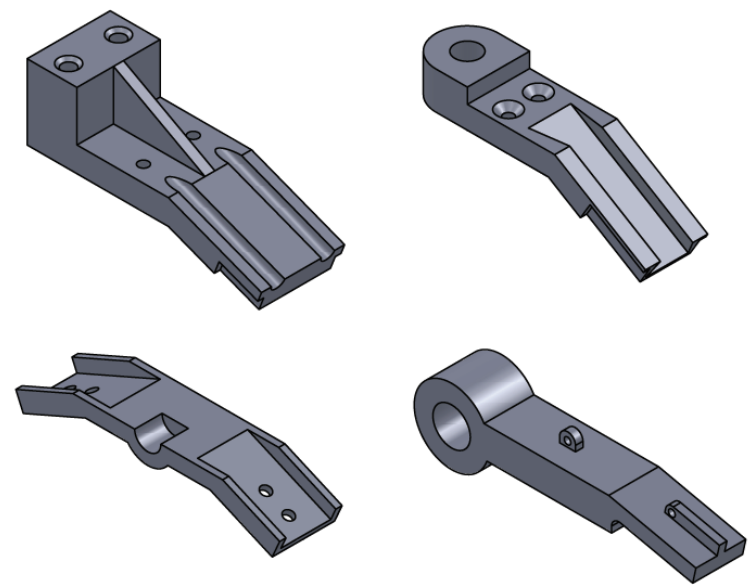

Figure 4. Models of second exercise

At the end of this part of the course students have to do the first test, which lasts an hour and a half and includes materials related to exercises 1 and 2 .

\subsection{Second part of the course}

In the exercise number three, students should model ten to twenty elements and mete them into adequate assembly. Students are shown how to create complex geometry parts and how to use the predefined parts from the toolbox. From the toolbox, students can use bolts, washers, nuts, bearings etc.(figure 5).
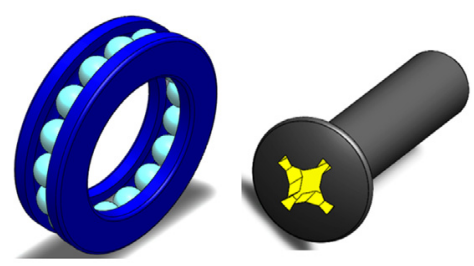

Figure 5. Bearing and screw

For students, third exercise is very demanding. They have to learn how to properly integrate all parts through the "mate" option in the assembly, taking care that some parts are fixed and some are mobile (float). An example of a third exercise assemblies is given in Figure 6.
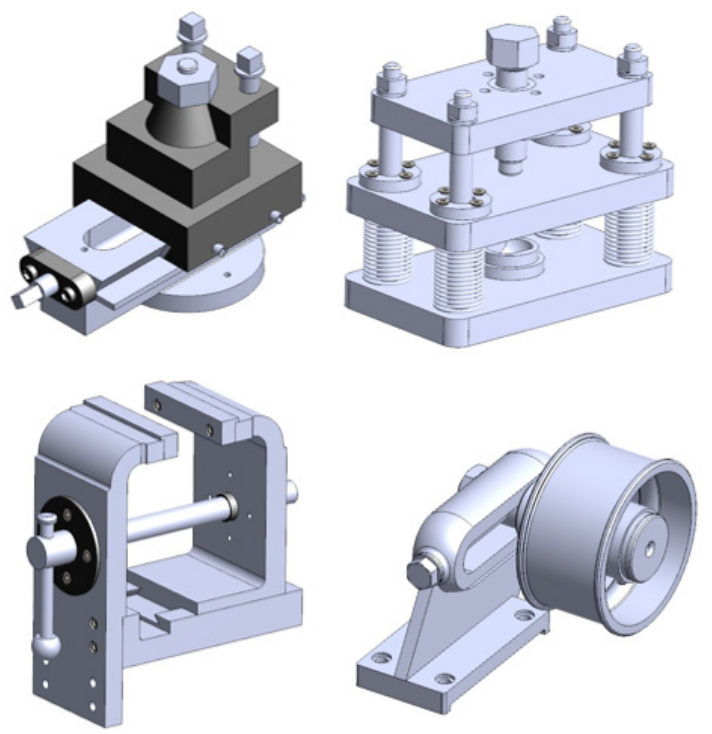

Figure 6. Models of third exercise 
At the end of this part of the course students have second test, which lasts an hour and a half and includes materials related to exercise number 1, 2 and 3 .

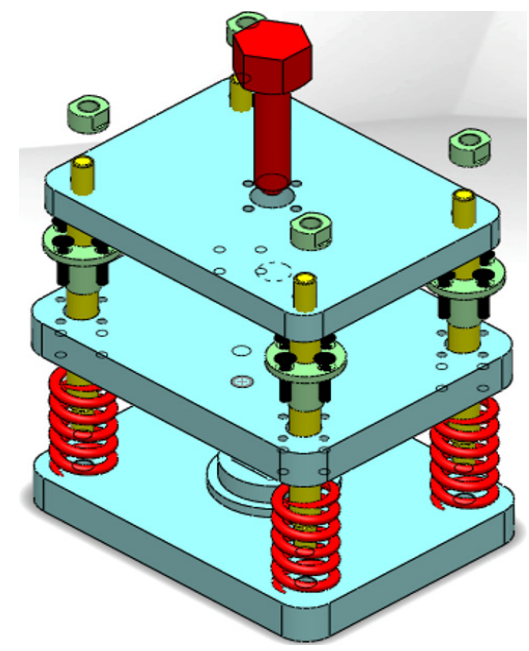

Figure 7. Model before assembling

\subsection{Third part of the course}

The last part of the course is about modelling turbines. Important command in the SolidWorks, that would make modelling of turbines much easier task, is Circular pattern. Some example of exercise number four is given in Figure 8.
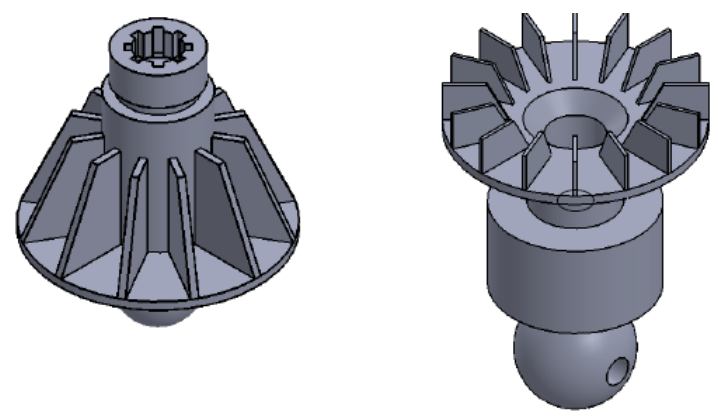

Figure 8. Models of fourth exercise

In this part of the course students learn about the quality of surface finish and how to add specific material properties to the $3 \mathrm{D}$ models.

At the end of this part of the course students are preparing for the third test. It lasts two hours and includes materials related to exercise number 4 .

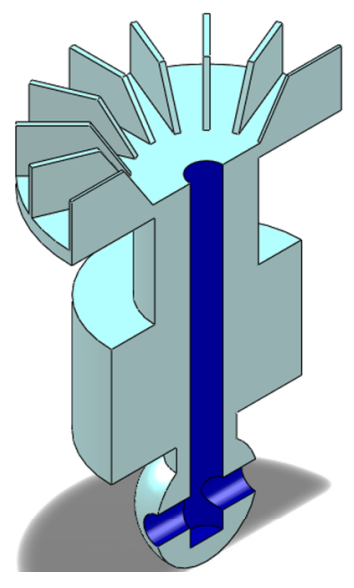

Figure 9. Cross section of the model

\section{OLD TEACHING METHODOLOGY}

Engineering Graphics course was organized in the second semester of the first year of studies. It lasts 15 weeks and it takes 3 hours a week. Students have access to four classrooms that are equipped with 20 computers each.

Students were gathered in one classroom equipped with video projector. Teacher performs exercises on one computer connected to that projector. Students follow the lecture via projected picture from the teacher's computer. Lecturing usually lasts for about an hour. It means that students have two hours to practice independently. It was an often case that some steps of the modelling procedure, shown during the lecture, was totally forgotten by students until the start of the exercises. In these cases, teacher had to go through all four classrooms and remind students about the missing steps in the modelling process. The problem was that all of these repetitions were about basic modelling techniques. Due to that, it was almost impossible to discuss about advanced modelling methodologies.

\subsection{Difficulties with the old teaching methodology}

The main reasons why we decided to implement a novel approach are the following:

$>$ Students were attending classes without any prior knowledge. A lot of time was spent for explaining the basics of 3D modelling process.

$>$ During the lectures students were passive and bored. It was a big hindrance to a learning process.

$>$ The lectures lacked teacher- student interaction, necessary for successful learning process.

$>$ Very often a lot of tasks shown during lectures had to be repeated afterwards, during exercise period. One teacher covering four classrooms made this task very challenging.

$>$ Because of the slow progress, students were losing interest for the subject very fast.

\section{NOVEL APPROACH}

Our main task was to take the teaching of the 3D modelling process basics out of the classroom. To make students do the basic preparations prior to coming to the class. To provide basic knowledge available to students $24 / 7$, at any place covered by internet. To support the students to prepare themselves for discussion during classes. To make them interested in the subject and wake up their competitive spirit. To provide them teaching methodology that suits them the best (young people these days get most of the needed information from video tutorials).

Video tutorials, covering all lectures and all needed SolidWorks features, were filmed and uploaded on YouTube. Every video lasts from 10 to 15 minutes. Those video tutorials explain every part of the subject curriculum in the step-by-step manner. Every teaching week has correspondent set of tutorials, that have to be acknowledged prior to classes. They are made for absolute beginners. No prior knowledge is needed. 
To motivate students to watch tutorial prior to coming to class, new weekly tests were established. Those were 10 minutes entry tests for that teaching week. The test task was to model a simple element by using the SolidWorks features explained in the tutorials for that week. Entry test results also influenced the subject final grade.

In this way, we can enrich the course with new commands in modeling. So in the course of the already mentioned commands we can add new ones: Offset entities, Linear Pattern, Swept Boss, Sketch Text etc.

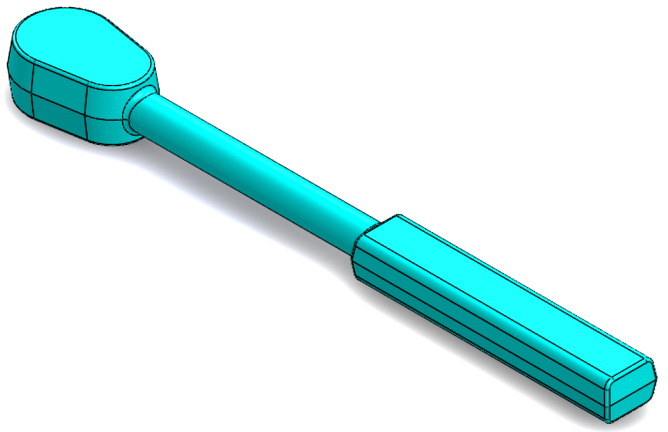

Figure 10. Key withaout hole

For models with a more complicated shape, the Offset entties option is more than desirable. For example, if we model the head of a key as shown at figure 10., and once done a sketch (Figure 11), it is not necessary to sketch again to form a hole of this shape.

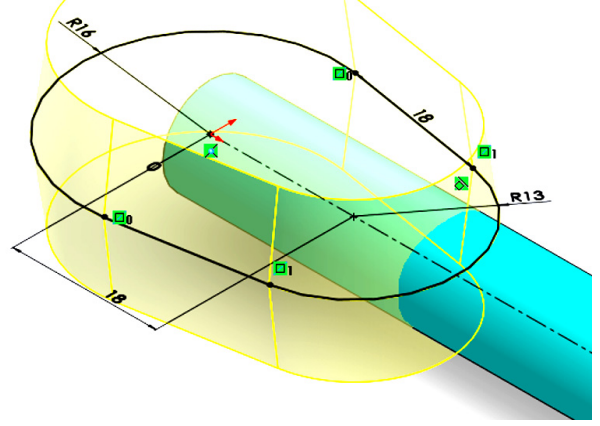

Figure 11. Sketch for the head of the key

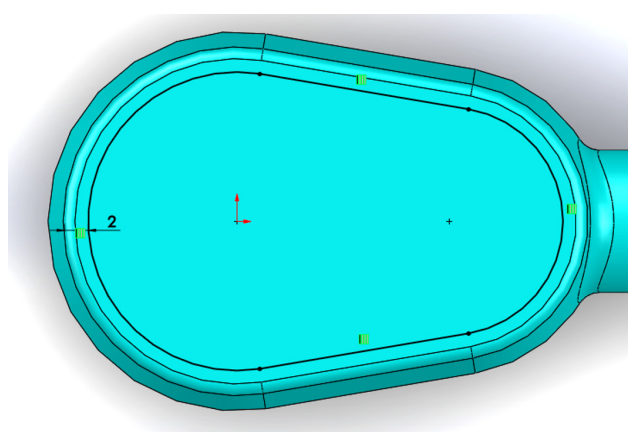

Figure 12. Sketch for hole made by Offset entities

We will use the Offset entities option and in combination with the Extruded Cut make a hole as is shown on the figure 13 .

We could introduce some more demanding tasks in terms of a more complicated form. Until now, no ellipsoid was used in the exercise model, and the model that combines ellipse and the Circular pattern option is shown in the Figure 14.

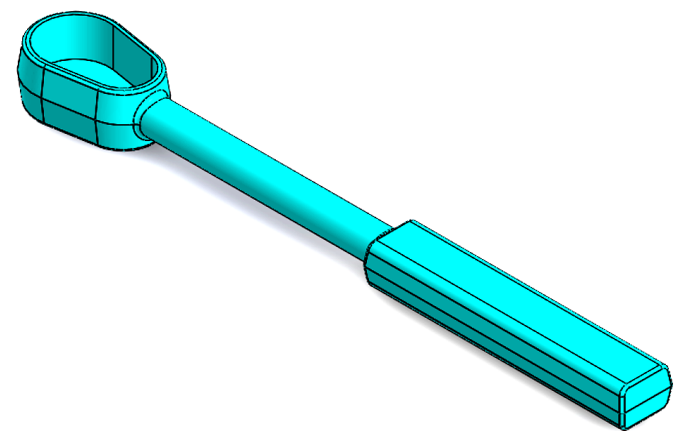

Figure 13. Key with hole

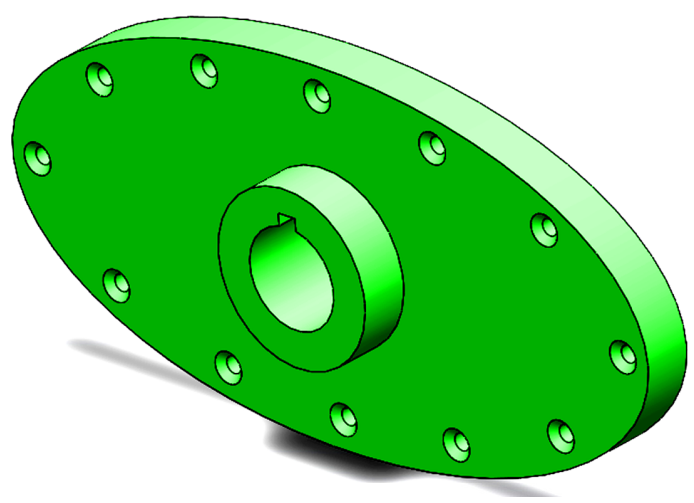

Figure 14. Display model of ellipse and circular pattern

The Sketch Text option is suitable for embossing the logo or some notes on the very parts. An example is the wheel in figure 15 with the text.
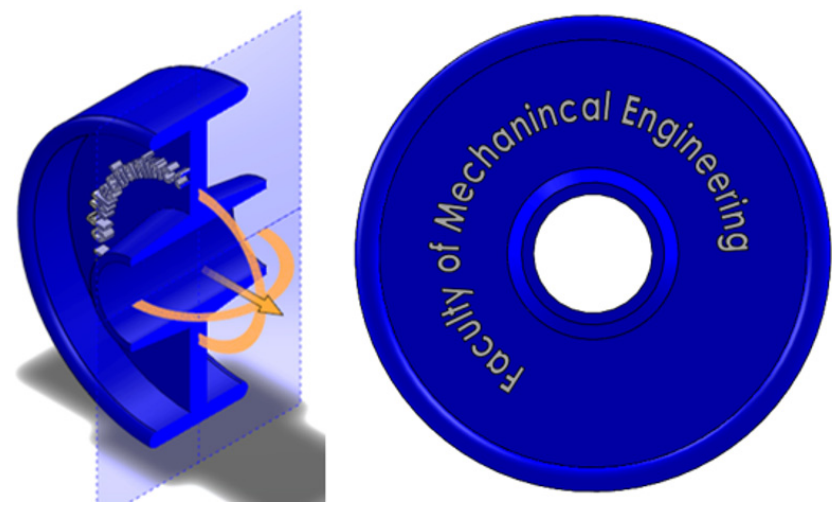

Figure 15. Wheel whith text

These are just some of the options that can be implemented in the course. The main reason is that with such an approach, all these commands can really be shown in lectures. The time spent on repeating the material and showing one option several times, now it can be spent on new options and thus increasing the quality of students' knowledge when they passing the exam.

\section{EMINENT ACHIEVEMENTS}

The first improvement noticeable in the teaching process was that students came to lectures prepared. They were familiar with the SolidWorks and 3D modelling terminology, with SolidWorks working environment and basic commands. It made the lecturing a whole new concept. Instead of spending time in covering the basics, right after the beginning of the class a dynamic discussion started almost every time. Students were giving their advanced solutions for problems that 
were covered in the tutorials. Very soon, they started to compete each other in explaining different approaches to specific element modelling.

Those competitions were fantastic for learning process, so we have established some quizzes in order to define some rules of competition and to apply prizes that will affect active students' final grades [9].

Classes came through fantastic transformation that no one really expected. From the classrooms full of bored students complaining about everything, we came to the situation that students wouldn't leave classrooms at the end of the classes. They started to enjoy in acknowledging new things.

\section{RESULTS}

Students' grades were followed for the past three years (since the new approach implementation). Their study results (average grade) and success rates (number of students that passed the exam) can be seen in table 1. It is evident that not only the teaching process and the classroom atmosphere is better, but also the statistics are better.

Table 1. The results of students

\begin{tabular}{|c|c|c|c|c|}
\hline \multirow[b]{2}{*}{ Criterion } & \multirow[b]{2}{*}{$\begin{array}{l}\text { Old teaching } \\
\text { methodology }\end{array}$} & \multicolumn{3}{|c|}{ Novel approach } \\
\hline & & $\begin{array}{c}\mathrm{I} \\
\text { year }\end{array}$ & $\begin{array}{c}\text { II } \\
\text { year }\end{array}$ & $\begin{array}{c}\text { III } \\
\text { year }\end{array}$ \\
\hline Average grade & 7.34 & 7.75 & 8.12 & 8.46 \\
\hline Success rate $(\%)$ & 62 & 75 & 79 & 82 \\
\hline
\end{tabular}

In this way much better cooperation between professors and students was achieved there was an increase in interest in overcoming not so easy material. At the end of each semester, students were able to anonymously comment on the course and evaluate teachers. Comments from year to year are getting better and there are almost no negative comments concerning teaching process.

\section{CONCLUSION}

As technology progresses, through generations, the areas of learning are changing, and therefore the methods of teaching. Previously, the focus was on manual drawing, while today is on mastering the software packages for technical documentation production. It is important to adjust the teaching to the group's needs. We realized that we needed to change our approach and move forward with technology.

The younger generations more easily learn through video tutorials, as shown in this paper. With this approach we have achieved that students learn during the entire course and come prepared for classes. This not only improved the quality of teaching process, but also the students' success rate and their average mark. Using modern software tools like Solidworks and Matlab Simulink a mathematical analysis of its mechanism for movement in a 3D environment can be performed [10].

The importance of $3 \mathrm{~d}$ and $2 \mathrm{~d}$ modeling is described in the paper [11] where the mentioned method uses known solutions for either $2 \mathrm{D}$ or $3 \mathrm{D}$ configurations containing only one crack, and takes into consideration the interaction effect between cracks. The SolidWorks package has a very wide spectrum and contributes to the development of numerical models as described in paper [12].

\section{ACKNOWLEDGMENT}

Authors gratefully acknowledge the financial support from the Ministry of Education, Science and Technological Development of the Republic of Serbia under the projects ON174004 and TR35002.

\section{REFERENCES}

[1] N. Martin-Dorta, J.L. Saorin, M. Contero.: Development of a Fast Remedial Course to Improve the Spatial Abilities of Engineering Student, Journal of Engineering Education (2008), pp. 505-513.

[2] R. Obradović, M. Vujanović, B. Popkonstantinović, D. Ivetić, P. Šiđanin - Study program Computer Graphics - Engineering Animation and their relation with modern Serbian CG Industry, The international conference wbcinno 2015, $18^{\text {th }}$ Sep. 2015, Novi Sad, Serbia, pp. 54-57.

[3] Z. Jeli, E. Veg, B. Popkonstantinovic, Lj. Miladinovic,: Analysis of educational process in subject constructive geometry and graphics at the Faculty of Mechanical engineering, 4th International Scientific Conference on Geometry and Graphics moNGeometrija 2014, Vlasina, Serbia.

[4] A. Eren.: Unidirectional cycles of boredom, boredom coping strategies, and engagement among prospective teachers, Soc Psychol Educ (2016) No. 19, pp. 895-924.

[5] G. S. Mason, T. Rutar Shuman, K. E. Cook: Comparing the Effectiveness of an Inverted Classroom to a Traditional Classroom in an Upper-Division Engineering Course, IEEE Transactions on education (2013) vol. 56, no. 4.

[6] Balać, M., Grbović, A., Petrović, A.: Numerical preditions of crack growth in a pressure vessel with welded nozzles, Structural integrity and life, Vol. 15, No 1 (2015), pp. 55-61.

[7] Bajić, D., Momčilović, N., Maneski, T., Balać, M., Kozak, D., Ćulafić, S.: Numerical and experimental determination of stress concentration factor for a pipe branch model, Tehnički vjesnik 24, 3(2017), 687-692.

[8] S. Ristevski, R. Tashevski, T. Rizov: Concept Design of a Sports Coupe with Ergonomic Analysis and Photorealistic Rendering, FME Transactions (2014) 45, 288-293.

[9] C. A. Bodnar, D. Anastasio, J. A. Enszer, D. D. Burkeyd: Engineers at Play: Games as Teaching Tools for Undergraduate Engineering Students, Jour-nal of Engineering Education (2016), Vol. 105, No. 1, pp. 147-200.

[10] Stevanović, I., Rašuo, B.: Development of a Miniature Robot Based on Experience Inspired by Nature, FME Transactions, Volume 45 No 1, 2017, pp. 189-197. 
[11] Kastratovic, G., Vidanovic, N., Grbovic, A., Rasuo, B.: Approximate determination of stress intensity factor for multiple surface cracks, FME Transactions, Vo. 46, No. 1, pp. 41-47, 2018.

[12] Petrasinovic, N., Petrasinovic, D., Rasuo, B., Milkovic, D.: Aircraft Duraluminium Wing Spar Fatique Testing, FME Transactions Vol. 45, pp. 531-536, 2017.

\section{ИМПЛЕМЕНТАЦИЈА ПРИСТУПА ОБРНУТЕ УЧИОНИЦЕ У КУРСУ ЗД МОДЕЛИРАҢА}

\section{А. Д. Јоксимовић, Е. А. Вег, В. Д. Симоновић,} М. М. Регодић, Г. Б. Шиниковић, Н. Губељак

3Д моделирање у SolidWorks-y ce предаје на Машинском факултету Универзитета у Београду (Србија) више од једне деценије. Као и свака нова вештина коју треба савладати, софтверски пакет SolidWorks захтева добро прилагођену методологију подучавања. Најбољи могући начин подучавања био би индивидуални менторски рад. Један професор по студенту, који би био апсолутно фокусиран на завршетак задатка студента, и пружио најбоље резултате. Нажалост, због недостатка наставног особља и великог броја студената, овај приступ није могућ. Уместо тога, један професор би представио задатак из ЗД моделирања групи од 80 студената. Они би пратили целокупну презентацију и тек када се заврши целокупна презентација, студенти би се поделили у четири учионице са по 20 рачунара и вежбали представљене задатке. Током последње деценије примећено је неколико великих проблема у овим наставним методама. Примењен је нови приступ настави. Овај рад представља нову методологију наставе и постигнуте резултате у побољшању наставног процеса. 